\title{
Cinética da fermentação e taxas de degradação de forrageiras tropicais em diferentes idades de corte estimadas pela técnica de produção de gases in vitro ${ }^{1}$
}

\author{
Paula Andrea Toro Velásquez², Telma Teresinha Berchielli 3,4 , Ricardo Andrade Reis ${ }^{3,4}$, Astrid \\ Rivera Rivera ${ }^{2}$, Paulo Henrique Moura Dian², Izabelle Auxiliadora Molina de Almeida Teixeira ${ }^{3}$
}

\footnotetext{
1 Pesquisa financiada pela FAPESP.

2 Programa de Pós-graduação em Zootecnia - UNESP/Jaboticabal.

${ }^{3}$ Departamento de Zootecnia - FCAV - UNESP/Jaboticabal. Membro do INCT-CA.

${ }^{4}$ Bolsista de Produtividade em Pesquisa do CNPq.
}

RESUMO - Avaliaram-se a cinética de fermentação e taxas de degradação de três espécies forrageiras tropicais (capins tanzânia, marandu e tifton 85), com três idades de corte (28, 35 e 42 dias) nos períodos de janeiro-março e abril-junho, mediante o uso da técnica de produção de gases in vitro. No período de janeiro-março, o capim-marandu apresentou os maiores valores de fração solúvel, degradabilidade potencial e degradabilidade efetiva a taxa de passagem de $2 \%$ /hora. No período de abril-junho, os capins marandu e tanzânia apresentaram resultados semelhantes para essas mesmas variáveis. Independentemente do período, o capim-tifton 85 apresentou os menores valores de fração solúvel, degradabilidade potencial e degradabilidade efetiva a $2 \%$ /hora e valores superiores de fração não-degradável. Em abril-junho, a idade de corte influenciou a fração solúvel e a produção de gases após 96 horas de incubação, cujos menores valores foram observados, de modo geral, aos 28 dias. As menores taxas de fermentação foram observadas para o capim-tifton 85 no período de abril-junho, independentemente da idade de corte.

Palavras-chave: capim-marandu, capim-tanzânia, capim-tifton 85, degradabilidade efetiva, degradabilidade potencial, fermentação

\section{Fermentation kinetic and degradation rates of tropical forages harvested in different ages evaluated by in vitro gas production technique}

\begin{abstract}
Fermentation kinetics and degradation rates of three tropical forage species (Tanzania grass, Marandu grass and Tifton 85 grass) were evaluated by the in vitro gas production technique. The forages were harvested at 28, 35 and 42 days of regrowth during two periods, January-March and April-June. In the January-March period, Marandu grass presented the greatest values of fraction A, potential degradability (PD) and effective degradability for a passage rate of $2 \% /$ hour (ED2). In the April-June period, Marandu and Tanzania grasses presented similar results for the variables tested above. In both periods, Tifton 85 had the lowest values of fraction A, PD and ED2, and the greatest value of fraction C. In the April-June period, there was an age effect in relation to gas production potential and 96 hours of incubation with the lowest value was found for 28 days of regrowth. The lowest fermentation rates were observed in general for Tifton 85 grass in the April-June period, regardless of the regrowth age.
\end{abstract}

Key Words: effective degradability, fermentation, marandu grass, potential degradability, tanzania grass, tifton 85 bermudagrass

\section{Introdução}

A técnica de produção de gases in vitro é importante no estudo dos parâmetros cinéticos das frações que compõem os alimentos, pois reflete a taxa e extensão em que os componentes são fermentados pelos microrganismos do rúmen (Cabral et al., 2002).

$\mathrm{O}$ estudo do valor nutritivo da forragem possibilita identificar as principais causas limitantes do nível de produção, o que permite deduzir estratégias de manejo para aumento da produção animal. Em decorrência da estacionalidade quantitativa e qualitativa observada ao longo do ano, observam-se índices zootécnicos inferiores ao potencial produtivo nas gramíneas tropicais. Além disso, o avanço na idade das plantas tem efeitos sobre a fração da parede celular que alteram a composição química e digestibilidade. 
Assim, objetivou-se estimar a cinética de degradação, a taxa de fermentação e a produção de ácidos graxos de cadeia curta (AGCC) de três forrageiras tropicais: marandu (Brachiaria brizantha cv. Marandu), tifton 85 (Cynodon spp) e tanzânia (Panicum maximum Jacq. cv. Tanzânia) em três idades de rebrota $(28,35$ e 42 dias) nos períodos de janeiro-março e abril-junho por meio da técnica de produção de gases in vitro.

\section{Material e Métodos}

O trabalho foi realizado na Faculdade de Ciências Agrárias e Veterinárias (Unesp), Campus de Jaboticabal, estado de São Paulo, Brasil.

A área total do experimento foi de $264 \mathrm{~m}^{2}$, divididos em áreas de $8 \times 11 \mathrm{~m}\left(88 \mathrm{~m}^{2}\right)$ por espécie, cada uma com três canteiros, um para cada idade de corte ( 28,35 e 42 dias). $O$ período experimental teve duração de 5 meses, de janeiro a junho de 2005. No início do experimento e depois de cada período de amostragem, todas as parcelas foram fertilizadas com nitrogênio (60 kg/ha) após o corte de uniformização, considerando as alturas de manejo de cada espécie (capimmarandu, $25 \mathrm{~cm}$; capim-tifton $85,15 \mathrm{~cm}$; capim-tanzânia, $30 \mathrm{~cm}$ ), a fim de uniformizar o crescimento das espécies.

A amostragem dos capins foi realizada adotando-se um quadrado de $1 \mathrm{~m}^{2}$ de área, o qual foi lançado ao acaso em três pontos do canteiro. A forragem encontrada dentro da área do quadrado foi cortada nas alturas de manejo de cada espécie. Após a coleta, as amostras foram pré-secas em estufa com circulação forçada a $55^{\circ} \mathrm{C}$, durante 72 horas. As amostras obtidas nos três pontos do canteiro foram homogeneizadas para representar a área em uma amostra composta, da qual foram utilizadas duas repetições em todas as análises. Posteriormente, o material foi pesado e triturado em moinho tipo Willey com peneira de malha de $1 \mathrm{~mm}$.

As amostras pré-secas foram utilizadas para determinação dos teores de matéria seca (MS), matéria orgânica (MO), fibra em detergente neutro (FDN), fibra em detergente ácido (FDA), fibra em detergente neutro corrigida para cinzas e proteína ( $\mathrm{FDNcp}$ ), lignina, proteína bruta (PB), nitrogênio insolúvel em detergente neutro (NIDN) e nitrogênio insolúvel em detergente ácido (NIDA) (Tabela 1), segundo procedimentos descritos por Silva \& Queiroz (2002).

Perfis acumulativos de produção de gases in vitro foram obtidos usando a metodologia de Theodorou et al. (1994), modificada por Mauricio et al. (1999), utilizando medidor de pressão e registrador de dados (PDL200, LANA/CENA-USP, Piracicaba, São Paulo, Brasil). O volume de gases produzidos foi medido com seringa para a construção da equação de produção de volume de gases.

$\mathrm{Na}$ fase laboratorial, foram incubadas oito garrafas por amostra para as medições da produção de gases e da degradabilidade aparente. Cada garrafa de vidro de $100 \mathrm{~mL}$ continha $0,6 \mathrm{~g}$ de amostra com $6 \mathrm{~mL}$ de inóculo e $54 \mathrm{~mL}$ de meio tampão de McDougal (McDougal, 1949), permitindo obter relação final de inóculo:meio 1:9. Essas garrafas foram seladas e mantidas a $39^{\circ} \mathrm{C}$ em estufa de ar forçado. As medições dos gases foram feitas $0,3,6,9,12,18,24,30,36$, 48, 60, 72 e 96 horas pós-incubação. Para os ajustes de variação, foram incubadas garrafas consideradas branco, contendo as soluções de incubação sem substrato e um padrão interno (feno de capim-tifton 85 ) com perfil da produção de gases conhecido.

Um dia antes da inoculação, as amostras foram pesadas, colocadas nas respectivas garrafas e mantidas a $39^{\circ} \mathrm{C}$. O meio de cultura foi preparado sob fluxo contínuo de $\mathrm{CO}_{2}$ e mantido em estufa a $39^{\circ} \mathrm{C}$, segundo técnica de Theodorou et al. (1994), modificada por Mauricio et al. (1999).

O inóculo ruminal foi obtido de bovinos da raça Nelore com peso médio de $278 \mathrm{~kg}$ e idade média de 24 meses, fistulados no rúmen. A dieta dos animais foi à base de forragem verde (Brachiaria brizantha), fornecida picada duas vezes ao dia. Durante o período de adaptação (15 dias), os animais foram alojados em baias individuais com dimensões de $3,00 \times 7,20 \mathrm{~m}$. A digesta do rúmen foi obtida com os animais em jejum coletando manualmente a fase sólida e a fase líquida do saco dorsal e ventral do rúmen, que, em seguida, foram armazenadas em garrafas térmicas pré-aquecidas a $39^{\circ} \mathrm{C}$ e imediatamente levadas ao laboratório. Volumes iguais das duas fases (líquida e sólida) foram misturados no liquidificador por aproximadamente 10 segundos sob infusão de $\mathrm{CO}_{2}$. Em seguida, o inóculo foi filtrado em duas camadas de tecido tipo fralda e mantido em banho-maria a $39^{\circ} \mathrm{C}$ com saturação de $\mathrm{CO}_{2}$ até a inoculação.

Para determinação da degradabilidade aparente nos horários 0,12 , 48 e 96 horas, foram incubadas oito garrafas por amostra de capim. Em cada horário, a fermentação foi interrompida e as garrafas colocadas em água a $4^{\circ} \mathrm{C}$. Uma alíquota do líquido da garrafa foi coletada e congelada para medição de ácidos graxos de cadeia curta (AGCC) (Leventini et al., 1990). Após degelo e centrifugação (14.000 rpm por 10 minutos), amostras do líquido incubado $(1 \mathrm{~mL})$ foram tratadas com $0,2 \mathrm{~mL}$ de ácido fórmico $(88 \%)$ para protonar os ácidos dissociados e garantir a volatilização dos AGCC no injetor do cromatógrafo. As análises dos AGCC foram conduzidas em cromatógrafo a gás (modelo CG 270, Instrumentos Científicos CG Ltda) com detector de 
ionização de chamas, empregando coluna empacotada ( $4 \%$ CW 20M Carbopack B-DA; 2,0 m × 1/8", fornecida pela empresa Analítica). As vazões de nitrogênio (gás de arraste), dos gases da chama $\mathrm{H}_{2}$ e do ar sintético foram mantidas em 30,30 e $300 \mathrm{~mL} /$ minutos, respectivamente. A temperatura do injetor, da coluna e do detector foram mantidas constantes em 180,188 e $240^{\circ} \mathrm{C}$, respectivamente.

O líquido e as partículas restantes foram filtrados em cadinhos $\mathrm{N}^{\circ} 1 \mathrm{com}$ porosidade de 100 a $160 \mu \mathrm{m}$ sob vácuo, para estimar a degradabilidade aparente. A degradação da matéria seca foi gerada por peso constante obtido por secagem a $100^{\circ} \mathrm{C}$ e a degradação da matéria orgânica, pela diferença do resíduo menos as cinzas obtidas a $500^{\circ} \mathrm{C}$ por 3 horas.

O modelo de France et al. (1993), adotado para estimar os padrões da fermentação microbiana, foi baseado na média da produção acumulada de gases de cada amostra e foi determinado por:

$$
\left.A=A f \times\left\{1-e^{[b \times(t-t o)-c \times(\sqrt{t}-\sqrt{t o})}\right]\right\}
$$

em que $A=$ volume acumulado de gases $(\mathrm{mL})$ produzidos até o tempo $t(\mathrm{~h}) ; A f=$ volume assintótico dos gases

Tabela 1 - Composição química dos capins marandu, tanzânia e tifton 85 em diversas idades de corte nos períodos de janeiro a março e abril a junho

\begin{tabular}{|c|c|c|c|c|}
\hline \multirow[t]{2}{*}{ Variável } & Idade de corte & Capim-marandu & Capim-tifton 85 & Capim-tanzânia \\
\hline & \multicolumn{4}{|c|}{ Janeiro - Março } \\
\hline \multirow[t]{3}{*}{ Fibra em detergente neutro ( $\%$ MS) } & 28 & 53,23 & 68,32 & 65,93 \\
\hline & 35 & 51,21 & 69,59 & 65,25 \\
\hline & 42 & 58,73 & 69,01 & 59,57 \\
\hline Fibra em detergente neutro corrigida & 28 & 42,35 & 62,06 & 60,16 \\
\hline \multirow[t]{2}{*}{ para cinzas e proteína $(\% \mathrm{MS})$} & 35 & 47,19 & 62,54 & 59,35 \\
\hline & 42 & 54,30 & 61,97 & 53,61 \\
\hline \multirow[t]{3}{*}{ Fibra em detergente ácido (\% MS) } & 28 & 20,96 & 31,59 & 33,14 \\
\hline & 35 & 26,44 & 31,59 & 31,89 \\
\hline & 42 & 33,33 & 31,74 & 33,47 \\
\hline \multirow[t]{3}{*}{ Lignina (\% MS) } & 28 & 2,06 & 3,54 & 2,15 \\
\hline & 35 & 2,34 & 3,65 & 2,15 \\
\hline & 42 & 2,43 & 2,73 & 2,45 \\
\hline \multirow[t]{3}{*}{ Proteína bruta (\% MS) } & 28 & 16,87 & 11,58 & 9,49 \\
\hline & 35 & 14,23 & 11,68 & 10,38 \\
\hline & 42 & 14,08 & 10,93 & 10,03 \\
\hline \multirow[t]{3}{*}{ Nitrogênio insolúvel em detergente neutro (\% MS) } & 28 & 1,43 & 1,10 & 0,87 \\
\hline & 35 & 1,25 & 1,15 & 0,89 \\
\hline & 42 & 1,36 & 1,13 & 0,86 \\
\hline \multirow[t]{4}{*}{ Nitrogênio insolúvel em detergente ácido (\% MS) } & 28 & 0,56 & 0,47 & 0,27 \\
\hline & 35 & 0,48 & 0,48 & 0,31 \\
\hline & 42 & 0,53 & 0,45 & 0,33 \\
\hline & \multicolumn{4}{|c|}{ Abril - Junho } \\
\hline \multirow[t]{3}{*}{ Fibra em detergente neutro ( $\%$ MS) } & 28 & 62,82 & 68,88 & 65,24 \\
\hline & 35 & 64,07 & 68,94 & 59,38 \\
\hline & 42 & 65,70 & 70,27 & 60,43 \\
\hline Fibra em detergente neutro corrigida & 28 & 59,28 & 60,60 & 58,96 \\
\hline \multirow[t]{2}{*}{ para cinzas e proteína $(\%$ MS $)$} & 35 & 60,98 & 58,85 & 52,10 \\
\hline & 42 & 63,10 & 63,18 & 54,87 \\
\hline \multirow[t]{3}{*}{ Fibra em detergente ácido (\% MS) } & 28 & 32,42 & 34,07 & 37,73 \\
\hline & 35 & 32,88 & 30,34 & 31,23 \\
\hline & 42 & 32,88 & 31,86 & 32,59 \\
\hline \multirow[t]{3}{*}{ Lignina (\% MS) } & 28 & 3,03 & 4,86 & 3,45 \\
\hline & 35 & 2,95 & 3,52 & 2,85 \\
\hline & 42 & 2,84 & 3,90 & 2,79 \\
\hline \multirow[t]{3}{*}{ Proteína bruta $(\% \mathrm{MS})$} & 28 & 13,45 & 13,41 & 12,17 \\
\hline & 35 & 11,22 & 15,19 & 13,55 \\
\hline & 42 & 9,88 & 13,44 & 12,33 \\
\hline \multirow[t]{3}{*}{ Nitrogênio insolúvel em detergente neutro (\% MS) } & 28 & 1,22 & 1,31 & 1,03 \\
\hline & 35 & 0,78 & 1,49 & 1,13 \\
\hline & 42 & 0,94 & 1,33 & 1,30 \\
\hline \multirow[t]{3}{*}{ Nitrogênio insolúvel em detergente ácido (\% MS) } & 28 & 0,48 & 0,62 & 0,40 \\
\hline & 35 & 0,43 & 0,66 & 0,47 \\
\hline & 42 & 0,34 & 0,54 & 0,56 \\
\hline
\end{tabular}


produzidos $(\mathrm{mL}) ; b$ e $c$ = parâmetros do modelo; e to = tempo de colonização discreto $(\mathrm{h})$.

A taxa de fermentação $\left(\mathrm{h}^{-1}\right)$ foi calculada de acordo com o modelo:

$$
\mu=\frac{b+c}{2 \times \sqrt{t}}
$$

O modelo de France et al. (1993) foi ajustado aos dados de produção de gases para estimar o tempo de colonização e a produção potencial de gases (A, assíntota de produção de gases do modelo utilizando-se o procedimento nãolinear do SAS (2001)). Com a produção acumulativa de gases às 48 e 96 horas após inoculação, foram calculados e comparados os quocientes entre a produção acumulativa de gases 96 horas após incubação e a produção potencial de gases, e os quocientes entre as produções acumulativas de gases após 48 e 96 horas de incubação, como aproximação para avaliar os alimentos, assumindo-se que o tempo médio de retenção no rúmen é de 48 horas. A relação entre a produção acumulativa de gases 96 horas após incubação e a produção potencial de gases representa a proximidade de produção acumulativa de gases 96 horas após incubação ao potencial de produção de gases A. A relação entre as produções de gases 48 e 96 horas após incubação sugere, proporcionalmente, quanto da produção total de gases determinada no ensaio (96 horas) foi realizada até às 48 horas de incubação.

Para ajustar os dados de degradabilidade às $0,12,48 \mathrm{e}$ $96 \mathrm{~h}$, foram utilizados os modelos matemáticos propostos por Mehrez \& Ørskov (1977) e Ørskov \& McDonald (1979), que possibilitaram estimar as degradabilidades potencial (DP) e efetiva (DE):

$D P=A \rightarrow t \leq L$

$\mathrm{DP}=\mathrm{a}+\mathrm{b}\left(1-\mathrm{e}^{-\mathrm{c} \times \mathrm{t}}\right) \rightarrow t>L$,

em que: DP = degradabilidade do alimento (\%) no tempo $\mathrm{t}$ (horas); $\mathrm{A}=$ fração prontamente solúvel (\%); $\mathrm{a} \mathrm{e} \mathrm{b}=$ parâmetros do modelo, cuja soma $(\mathrm{a}+\mathrm{b})$ corresponde numericamente à degradabilidade potencial do alimento; $\mathrm{e}$ $\mathrm{c}=$ taxa de degradação (\%/hora).

Calculou-se também a fração insolúvel potencialmente fermentescível do alimento (B): $\mathrm{B}=(\mathrm{a}+\mathrm{b})-\mathrm{A}$ ou $100-(\mathrm{A}+\mathrm{C})$; em que $C$ representa a fração indegradável (calculada como 100-DP).

A degradabilidade efetiva (DE) dos alimentos foi calculada da seguinte forma:

$$
D E=a+b\left[\frac{c}{(c+k p)}\right],
$$

em que $\mathrm{kp}=$ taxa de passagem do alimento (\%/hora) pelo rúmen e foi considerada como $2 \%$ /hora.

Para a produção de gases e degradabilidade aparente, o delineamento experimental foi inteiramente casualizado, com os tratamentos distribuídos em esquema fatorial $3 \times 3$ com os fatores: espécies (capins tanzânia, marandu e tifton 85$)$, idades de corte $(28,35$ e 42 dias), com oito repetições (garrafas) por amostra.

O delineamento experimental utilizado na medição dos ácidos graxos de cadeia curta (AGCC) nas duas épocas do ano (janeiro a março e abril a junho) foi o inteiramente casualizado, em esquema fatorial $3 \times 3 \times 4$, composto dos fatores espécies (capins tanzânia, marandu e tifton 85), idades de corte ( 28,35 e 42 dias), tempo de incubação ( $0,12,48$ e 96 horas) e 2 repetições (provenientes da amostra composta).

Os resultados foram submetidos à análise de variância e comparação de médias pelo teste de Tukey, de acordo com o programa estatístico SAS (2001) a 5\% de significância.

\section{Resultados e Discussão}

Considerando que as características das plantas forrageiras que formam uma pastagem podem ser potencializadas ou suprimidas de acordo com as condições do meio e manejo impostas e analisando as alturas de corte (tanzânia: $30 \mathrm{~cm}$, marandu: $25 \mathrm{~cm}$, tifton 85: $15 \mathrm{~cm}$ ), em geral, as espécies com hábito de crescimento cespitoso (capins tanzânia e marandu) foram favorecidas pela eliminação dos meristemas apicais, o que estimula o surgimento de tecidos novos nas plantas, desde as gemas basais, fato não observado no capim-tifton 85 , que, por suas características de crescimento estolonífero, fez com que o meristema apical continuasse na planta, tendo resposta de crescimento sem renovação de tecidos que suportam a parte aérea e acumulação de material morto.

No período de janeiro-março, constatou-se efeito das espécies $(\mathrm{P}<0,05)$ na fração prontamente solúvel $(\mathrm{A})$, na fração indegradável $(\mathrm{C})$, na degradabilidade potencial (DP) e na degradabilidade efetiva a $2 \%$ /hora, de modo que o capim-marandu apresentou os maiores valores de fração solúvel, degradabilidade potencial e degradabilidade efetiva e o capim-tifton 85 , os maiores valores para a fração insolúvel (Tabela 2).

A idade de corte influenciou os valores da fração A ( $P<0,05)$, que foram maiores aos 35 dias de rebrota $(21,56 \%)$, porém não diferiram dos obtidos no corte realizado aos 28 dias (20,17\%). Houve interação significativa espécies $\times$ idades de corte para a fração insolúvel $(\% / h)$, cujos valores foram maiores aos 42 dias no capim-marandu. Esses valores obtidos aos 42 dias nesta gramínea não diferiram do obtido no corte aos 28 dias.

No período de abril a junho (Tabela 3), o capim-tifton 85 apresentou os menores valores $(\mathrm{P}<0,05)$ da fração solúvel, 
de degradabilidade potencial e de degradabilidade efetiva e maiores valores da fração insolúvel, enquanto os capins marandu e tanzânia apresentaram resultados semelhantes para essas frações. A idade de corte não influenciou nenhum parâmetro neste período e os maiores valores de fração solúvel e degradações potenciais e efetivas foram obtidos na primeira época, seguindo a tendência de redução na qualidade das gramíneas na segunda época. É possível que esse fato esteja relacionado às temperaturas e precipitações médias, que foram menores no período de abril a junho $\left(21,4^{\circ} \mathrm{C}\right.$ e $\left.72,4 \mathrm{~mm}\right)$ em comparação ao período de janeiro a março $\left(24,2^{\circ} \mathrm{Ce} 189,2 \mathrm{~mm}\right)$.

No período de janeiro a março, foram observadas diferenças entre as espécies $(\mathrm{P}<0,05)$ em relação ao tempo de colonização e à produção de gases após 96 horas de incubação (Tabela 4). No capim-tifton 85 , o tempo de colonização foi superior ao do capim-tanzânia, porém semelhante ao do capim-marandu. Não houve diferença significativa entre as idades de corte nem interação espécie $\times$ idades

Semelhante ao período de janeiro a março, nos meses de abril a junho, a produção de gases após 96 horas de incubação do capim-marandu foi superior à do capim-tifton 85, entretanto, não diferiu do capim-tanzânia. A idade de corte influenciou $(\mathrm{P}<0,05)$ a produção potencial de gases e a produção de gases 96 horas após a incubação, cujos menores valores foram observados, de modo geral, aos 28 dias. Não se constatou interação espécie $\times$ idades de corte.

A FDN dos alimentos apresenta um período de colonização no qual não se verifica degradação do substrato. O capim-tifton 85 apresentou maiores valores de tempo de colonização, possivelmente em decorrência dos maiores valores de FDN e lignina em relação às demais gramíneas avaliadas (Tabela 1). Todavia, o tempo de

Tabela 2 - Parâmetros das equações de degradabilidade obtidas pela técnica de produção de gases em amostras dos capins marandu, tifton 85 e tanzânia em três idades de corte no período de janeiro a março

\begin{tabular}{|c|c|c|c|c|c|}
\hline \multirow[b]{2}{*}{ Variável } & \multirow[b]{2}{*}{ Idade de corte } & \multicolumn{3}{|c|}{ Espécie } & \multirow[b]{2}{*}{ Média } \\
\hline & & Capim-marandu & Capim-tifton 85 & Capim-tanzânia & \\
\hline & \multicolumn{5}{|c|}{ Janeiro - Março } \\
\hline \multirow{4}{*}{ Fração solúvel (\%) } & 28 & 25,48 & 15,85 & 19,17 & $20,17 \mathrm{AB}$ \\
\hline & 35 & 25,95 & 15,65 & 23,09 & $21,56 \mathrm{~A}$ \\
\hline & 42 & 21,04 & 15,30 & 18,23 & $18,19 \mathrm{~B}$ \\
\hline & Média & $24,16 \mathrm{a}$ & $15,60 \mathrm{c}$ & $20,16 b$ & \\
\hline Coeficiente de variação (\%) & & 7,21 & & & \\
\hline Fração insolúvel potencialmente & 28 & 47,09 & 46,83 & 51,75 & 48,56 \\
\hline \multirow[t]{3}{*}{ degradável (\%) } & 35 & 49,30 & 49,25 & 44,06 & 47,54 \\
\hline & 42 & 51,03 & 53,54 & 50,73 & 51,77 \\
\hline & Média & 49,14 & 49,87 & 48,85 & \\
\hline Coeficiente de variação (\%) & & 5,34 & & & \\
\hline \multirow{4}{*}{ Fração insolúvel (\%) } & 28 & 23,04 & 37,32 & 29,07 & 29,81 \\
\hline & 35 & 20,05 & 35,10 & 32,84 & 29,33 \\
\hline & 42 & 27,93 & 31,15 & 31,03 & 30,04 \\
\hline & Média & $23,67 b$ & $34,52 \mathrm{a}$ & $30,98 b$ & \\
\hline Coeficiente de variação (\%) & & 8,82 & & & \\
\hline \multirow[t]{4}{*}{ Fração insolúvel (\%/hora) } & 28 & $4,07 \mathrm{aAB}$ & $3,20 \mathrm{aA}$ & $2,97 \mathrm{aA}$ & 4,79 \\
\hline & 35 & $3,10 \mathrm{aB}$ & $3,07 \mathrm{aA}$ & $3,69 \mathrm{aA}$ & 3,24 \\
\hline & 42 & $5,46 \mathrm{aA}$ & $2,71 \mathrm{bA}$ & $3,20 \mathrm{bA}$ & 3,79 \\
\hline & Média & 4,21 & 2,99 & 3,29 & \\
\hline Coeficiente de variação (\%) & & 13,10 & & & \\
\hline \multirow[t]{4}{*}{ Tempo de colonização (hora) } & 28 & 0,37 & 0,40 & 0,38 & 0,39 \\
\hline & 35 & 0,43 & 0,38 & 0,36 & 0,39 \\
\hline & 42 & 0,38 & 0,38 & 0,39 & 0,39 \\
\hline & Média & 0,40 & 0,39 & 0,38 & \\
\hline Coeficiente de variação (\%) & & 3,93 & & & \\
\hline \multirow[t]{4}{*}{ Degradabilidade potencial (\%) } & 28 & 72,57 & 62,68 & 70,92 & 68,85 \\
\hline & 35 & 78,96 & 64,90 & 67,15 & 70,34 \\
\hline & 42 & 72,07 & 68,84 & 68,96 & 69,96 \\
\hline & Média & $73,30 \mathrm{a}$ & $65,48 b$ & $69,01 \mathrm{~b}$ & \\
\hline Coeficiente de variação (\%) & & 3,59 & & & \\
\hline Degradabilidade efetiva a taxa & 28 & 57,07 & 44,31 & 50,03 & 50,47 \\
\hline \multirow[t]{3}{*}{ de passagem de $2 \% /$ hora } & 35 & 55,87 & 45,47 & 51,66 & 51,00 \\
\hline & 42 & 58,40 & 46,12 & 49,40 & 51,31 \\
\hline & Média & $57,12 \mathrm{a}$ & $45,30 \mathrm{c}$ & $50,36 b$ & \\
\hline Coeficiente de variação (\%) & & 4,57 & & & \\
\hline
\end{tabular}

Médias seguidas de letras iguais minúsculas na linha e maiúsculas na coluna não diferem $(\mathrm{P}>0,05)$ entre si pelo teste de Tukey. 
Tabela 3 - Parâmetros das equações de degradabilidade obtidas pela técnica de produção de gases em amostras dos capins marandu, tifton 85 e tanzânia em três idades de corte no período de abril a junho

\begin{tabular}{|c|c|c|c|c|c|}
\hline \multirow[b]{2}{*}{ Variável } & \multirow[b]{2}{*}{ Idade de corte } & \multicolumn{3}{|c|}{ Espécie } & \multirow[b]{2}{*}{ Média } \\
\hline & & Capim-marandu & Capim-tifton 85 & Capim-tanzânia & \\
\hline & \multicolumn{5}{|c|}{ Abril - Junho } \\
\hline \multirow[t]{4}{*}{ Fração solúvel (\%) } & 28 & 17,40 & 14,03 & 17,45 & 16,29 \\
\hline & 35 & 18,17 & 14,96 & 18,37 & 15,61 \\
\hline & 42 & 17,36 & 13,61 & 19,99 & 16,99 \\
\hline & Média & $16,08 \mathrm{a}$ & $14,20 \mathrm{~b}$ & $18,60 \mathrm{a}$ & \\
\hline \multirow[t]{3}{*}{ degradável $(\%)$} & 35 & 47,62 & 49,91 & 49,93 & 49,15 \\
\hline & 42 & 51,56 & 46,95 & 46,69 & 48,40 \\
\hline & Média & 49,88 & 46,19 & 47,81 & \\
\hline Coeficiente de variação (\%) & & 7,26 & & & \\
\hline \multirow[t]{2}{*}{ Fração insolúvel (\%) } & 28 & 32,12 & 44,26 & 35,73 & 37,37 \\
\hline & 35 & 34,21 & 35,13 & 31,69 & 33,68 \\
\hline & 35 & 3,30 & 2,81 & 3,02 & 3,04 \\
\hline & 42 & 3,19 & 2,77 & 2,45 & 2,80 \\
\hline & Média & 3,31 & 2,96 & 2,75 & \\
\hline Coeficiente de variação (\%) & & 12,73 & & & \\
\hline \multirow[t]{4}{*}{ Tempo de colonização (hora) } & 28 & 0,38 & 0,38 & 0,38 & 0,38 \\
\hline & 35 & 0,41 & 0,40 & 0,37 & 0,39 \\
\hline & 42 & 0,38 & 0,40 & 0,37 & 0,39 \\
\hline & Média & 0,39 & 0,39 & 0,37 & \\
\hline Coeficiente de variação (\%) & & 4,21 & & & \\
\hline \multirow[t]{3}{*}{ Degradabilidade potencial $(\%)$} & 28 & 67,87 & 55,74 & 64,27 & 62,63 \\
\hline & 35 & 65,79 & 64,86 & 68,31 & 66,32 \\
\hline & 42 & 68,92 & 60,56 & 66,68 & 65,39 \\
\hline
\end{tabular}

Médias seguidas de letras iguais minúsculas na linha e maiúsculas na coluna não diferem $(\mathrm{P}>0,05)$ entre si pelo teste de Tukey.

colonização obtido nas três gramíneas, nos dois períodos avaliados, foram inferiores aos valores reportados por Bueno et al. (2005), de 8,92 e 6,79 horas para feno de Brachiaria decumbens cv. Basilinsk aos 28 ou 56 dias de rebrota, respectivamente.

O valor da relação entre as produções de gases após 96 horas e a produção potencial de gases foi entre 0,88 e 0,92 , ou seja, foi obtido 88 a $92 \%$ do potencial durante o ensaio de produção de gases, comprovando que a incubação por 96 horas foi suficiente para atingir os objetivos propostos pela técnica de produção de gases in vitro.

Assumindo-se uma taxa de passagem da digesta ruminal (Kp) de 0,0208 $\mathrm{h}^{-1}$ e tempo médio de retenção no rúmen de 48 horas, espera-se que a maior fermentação ocorra nesse período, ou seja, quando o valor da relação entre a produção de gases após 48 e 96 horas é próximo de 1, o alimento é considerado de boa qualidade fermentativa. O maior valor dessa relação foi obtido com o capim-marandu, independentemente do período avaliado, e o valor mais baixo foi apresentado pelo capim-tifton 85 na época de abril-junho, todavia, sem efeito significativo da espécie e da idade de corte (Tabela 4).

No período de janeiro a março, os valores máximos encontrados para taxa de fermentação $(\mu)$ após 6 horas de incubação (Figuras 1, 2 e 3 ) foram observados para o capim-tifton 85 aos 42 dias, capim-tanzânia aos 28 dias e capim-tifton 85 aos 28 dias $\left(0,052 ; 0,050\right.$ e $0,049 \mathrm{~h}^{-1}$, respectivamente). No período de abril a junho, os maiores valores da taxa de fermentação foram observados para os capins marandu aos 42 dias, marandu aos 28 dias e tanzânia aos 42 dias $\left(0,050 ; 0,043\right.$ e $0,043 \mathrm{~h}^{-1}$, respectivamente). Esses valores são altos em comparação aos relatados por 
Nogueira Filho et al. (2000) para Brachiaria humidicola e Cynodon dactylon de 0,016 e $0,022 \mathrm{~h}^{-1}$, respectivamente, após 6 horas de incubação.

No período de janeiro-março, os maiores valores da taxa de fermentação após 48 horas de incubação foram observados para os capins tifton 85 aos 42 dias, tanzânia aos 28 dias e tifton 85 aos 28 dias $\left(0,019 ; 0,018\right.$ e $0,017 \mathrm{~h}^{-1}$, respectivamente). Em abril a junho, os maiores valores foram observados para os capins marandu aos 42 dias, tanzânia aos 42 dias e marandu aos 28 dias $(0,018 ; 0,015$ e $0,015 \mathrm{~h}^{-1}$, respectivamente). Os valores encontrados por Nogueira Filho et al. (2000) para Brachiaria humidicola e Cynodon dactylon após 48 horas de incubação foram de 0,020 e $0,028 \mathrm{~h}^{-1}$, respectivamente.

As menores taxas de fermentação foram observadas para o capim-tifton 85 no período de abril a junho (Figura 2b), independentemente da idade de corte.

Ácidos graxos de cadeia curta são os principais produtos da fermentação ruminal, principalmente o acético, o propiônico e o butírico. As taxas de produção desses ácidos graxos variam com o tempo após a ingestão e com o tipo de alimento (Kozloski, 2002).

No período de janeiro a março, a produção total de ácidos graxos de cadeia curta e a relação ácido acético:ácido propiônico diferiram $(\mathrm{P}<0,05)$ entre as espécies. A utilização do capim-marandu como substrato pelos microrganismos para a produção de ácidos graxos totais resultou em maiores concentrações $(44,96 \mu \mathrm{mol} / \mathrm{mL})$, mas os valores não diferiram do observado no capim-tanzânia $(43,81 \mu \mathrm{mol} / \mathrm{mL})$. Todavia, a fermentação do capim-marandu apresentou a menor relação ácido acético:ácido propiônico, o que está relacionado ao fato de esta gramínea ter apresentado os maiores conteúdos de ácido propiônico.

Houve interação espécie $\times$ idade de corte nas produções de ácido propiônico e butírico. As maiores produções de ácido propiônico aos 28 e 35 dias de rebrota foram obtidas, de modo geral, pela utilização do capim-marandu como substrato pelos microrganismos. Valores superiores de ácido

Tabela 4 - Parâmetros da produção in vitro de gases dos capins marandu, tanzânia e tifton 85

\begin{tabular}{|c|c|c|c|c|c|c|c|c|}
\hline & \multicolumn{8}{|c|}{ Variável } \\
\hline & $\begin{array}{l}\text { Fração } \\
\text { solúvel } \\
(\mathrm{mL} / \mathrm{g})\end{array}$ & $\begin{array}{c}\text { Fração } \\
\text { potencialmente } \\
\text { degradável }\end{array}$ & $\begin{array}{l}\text { Fração } \\
\text { insolúvel }\end{array}$ & $\begin{array}{c}\text { Tempo } \\
\text { de } \\
\text { colonização } \\
\text { (h) }\end{array}$ & $\begin{array}{l}\text { Produção de } \\
\text { gases após } \\
48 \text { horas de } \\
\text { incubação } \\
(\mathrm{mL} / \mathrm{g})\end{array}$ & $\begin{array}{c}\text { Produção } \\
\text { de gases após } \\
96 \text { horas de } \\
\text { incubação } \\
(\mathrm{mL} / \mathrm{g})\end{array}$ & REL1 & REL2 \\
\hline Espécie & \multicolumn{8}{|c|}{ Janeiro - Março } \\
\hline Capim-tanzânia & 285,22 & $0,025 \mathrm{~B}$ & $-0,042 \mathrm{~A}$ & $2,17 \mathrm{~B}$ & 171,56 & $247,61 \mathrm{AB}$ & 0,88 & 0,69 \\
\hline \multicolumn{9}{|l|}{ Idade de corte } \\
\hline 28 & 275,62 & 0,033 & $-0,096$ & 2,17 & 177,87 & 245,46 & 0,89 & 0,72 \\
\hline 35 & 281,98 & 0,036 & $-0,113$ & 2,31 & 179,49 & 251,33 & 0,90 & 0,71 \\
\hline 42 & 275,87 & 0,040 & $-0,157$ & 3,71 & 175,49 & 254,03 & 0,93 & 0,69 \\
\hline \multicolumn{9}{|l|}{ Probabilidade pelo teste $\mathrm{F}$} \\
\hline Coeficiente de variação (\%) & \multicolumn{8}{|c|}{ Abril - Junho } \\
\hline Capim-marandu & 263,27 & $0,043 \mathrm{~A}$ & $-0,186$ & 4,25 & 173,98 & $242,35 \mathrm{~A}$ & 0,92 & 0,72 \\
\hline Capim-tifton & 250,37 & $0,040 \mathrm{AB}$ & $-0,180$ & 5,06 & 151,84 & $225,49 \mathrm{~B}$ & 0,90 & 0,67 \\
\hline Capim-tanzânia & 259,55 & $0,037 \mathrm{~B}$ & $-0,130$ & 3,10 & 161,70 & $235,79 \mathrm{AB}$ & 0,91 & 0,69 \\
\hline \multicolumn{9}{|l|}{ Idade de corte } \\
\hline 28 & $247,32 \mathrm{~B}$ & 0,038 & $-0,147$ & 3,59 & 154,70 & $221,77 \mathrm{~B}$ & 0,90 & 0,70 \\
\hline 35 & $272,33 \mathrm{~A}$ & 0,039 & $-0,156$ & 3,93 & 172,09 & $245,79 \mathrm{~A}$ & 0,90 & 0,70 \\
\hline 42 & $253,53 \mathrm{AB}$ & 0,044 & $-0,194$ & 4,85 & 160,72 & $236,06 \mathrm{~A}$ & 0,93 & 0,68 \\
\hline \multicolumn{9}{|l|}{ Probabilidade pelo teste $F$} \\
\hline Espécie & 0,298 & 0,037 & 0,050 & 0,093 & 0,079 & 0,012 & 0,686 & 0,577 \\
\hline Idade de corte & 0,030 & 0,154 & 0,113 & 0,278 & 0,171 & 0,001 & 0,284 & 0,889 \\
\hline
\end{tabular}

Médias seguidas de letras iguais na coluna, dentro de cada fator, não diferem ( $P>0,05)$ estatisticamente entre si pelo teste de Tukey. REL1 - relação entre as produções de gases após 96 horas e a produção potencial de gases, REL2 - relação entre as produções de gases após 48 e 96 horas. 

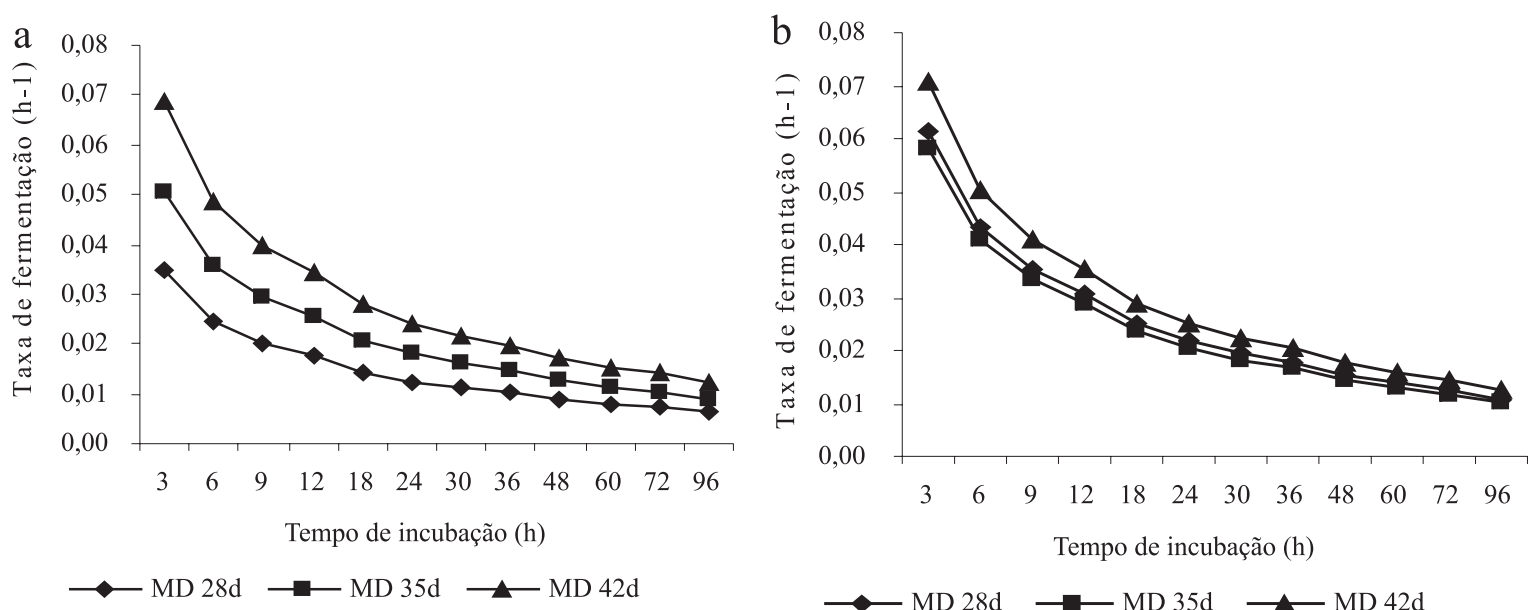

Figura 1 - Taxa de fermentação $(\mu)$ do capim-marandu em diferentes idades de corte $(28,35$ e 42 dias $)$ nos períodos de janeiro a março (a) e abril a junho (b).
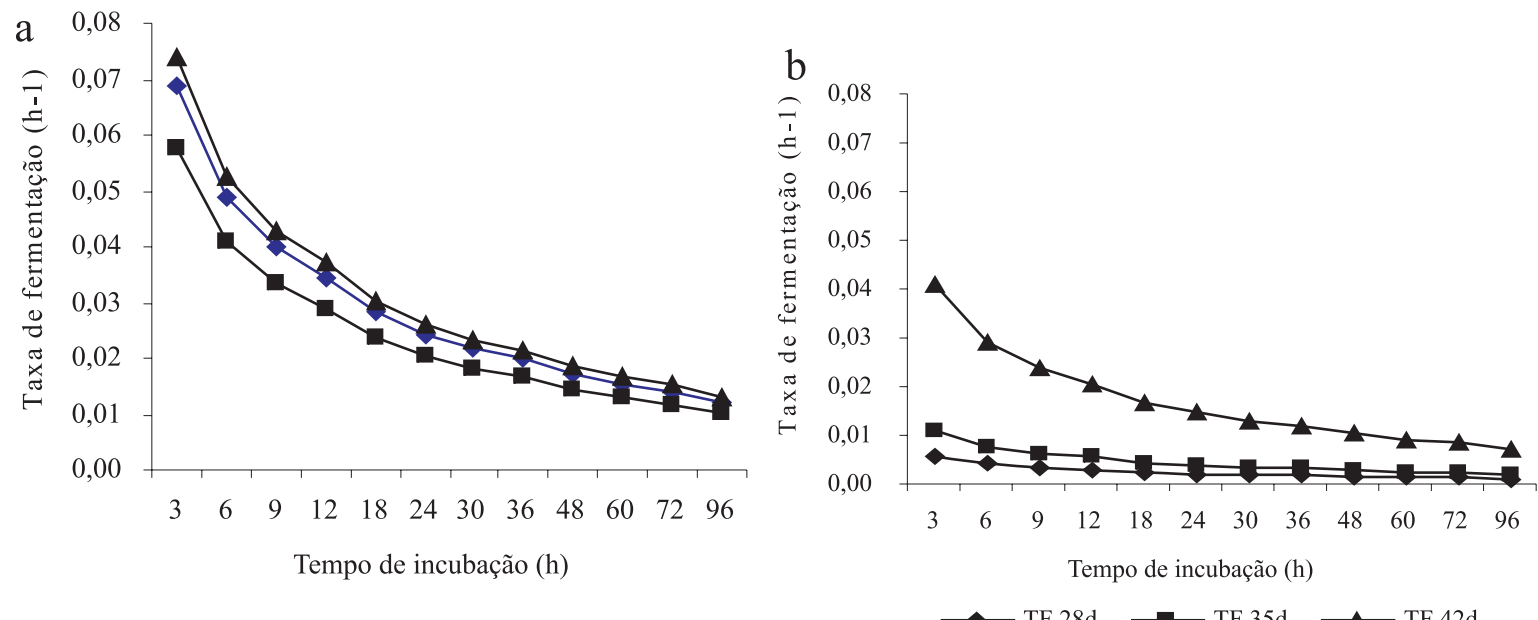

Figura 2 - Taxa de fermentação $(\mu)$ do capim-tifton 85 em diferentes idades de corte $(28,35$ e 42 dias $)$ nos períodos de janeiro a março (a) e abril a junho (b)
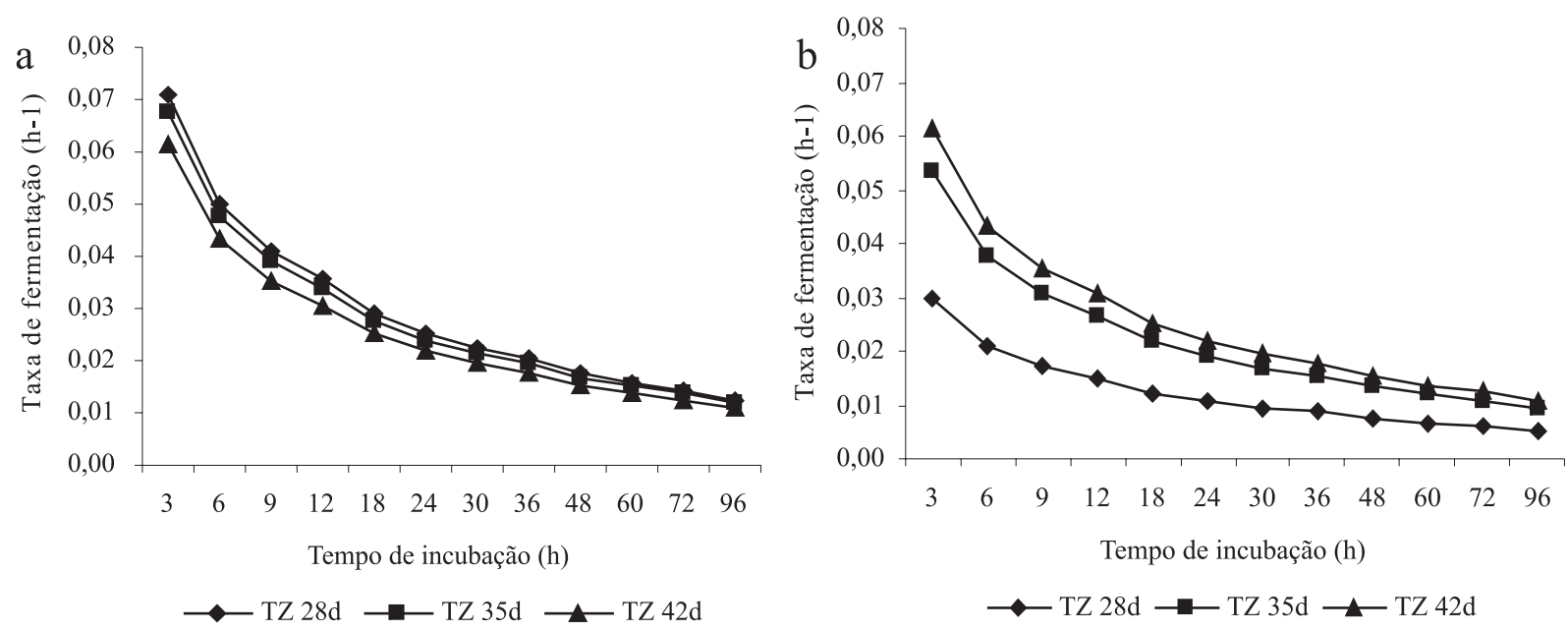

Figura 3 - Taxa de fermentação $(\mu)$ do capim-tanzânia em diferentes idades de corte $(28,35$ e 42 dias $)$ nos períodos de janeiro a março (a) e abril a junho (b). 
butírico foram obtidos quando os microrganismos tiveram como substrato o capim-marandu aos 28 dias de rebrota em comparação às demais espécies e idades de corte avaliadas.

No decorrer da incubação, houve aumento $(\mathrm{P}<0,05)$ na produção de ácidos graxos de cadeia curta, confirmando que as taxas de produção desses ácidos graxos variam com o tempo após a ingestão. A interação espécie $\times$ tempo de incubação foi significativa para todas as variáveis no período de janeiromarço, com exceção da relação acético:propiônico (Figura 4), no entanto, não foi observada interação idade de corte $\times$ tempo de incubação.

No período de abril a junho, a fermentação do capimtifton 85 por microrganismos proporcionou as menores concentrações de ácidos graxos de cadeia curta totais. Assim como no período de janeiro a março, a menor relação acético:propiônico foi obtida quando o capim-marandu foi utilizado como substrato.

Nesse período, a idade de corte influenciou $(\mathrm{P}<0,05)$ as produções de ácidos graxos de cadeia curta totais e de ácido acético, com destaque para gramíneas com 35 dias, que apresentaram as maiores produções, porém não diferindo do corte realizado aos 42 dias.

Houve interação espécies $\times$ idade de corte para as produções de ácidos propiônico e butírico. As menores produções desses ácidos graxos voláteis foram obtidas, de modo geral, quando o substrato utilizado pelos microrganismos
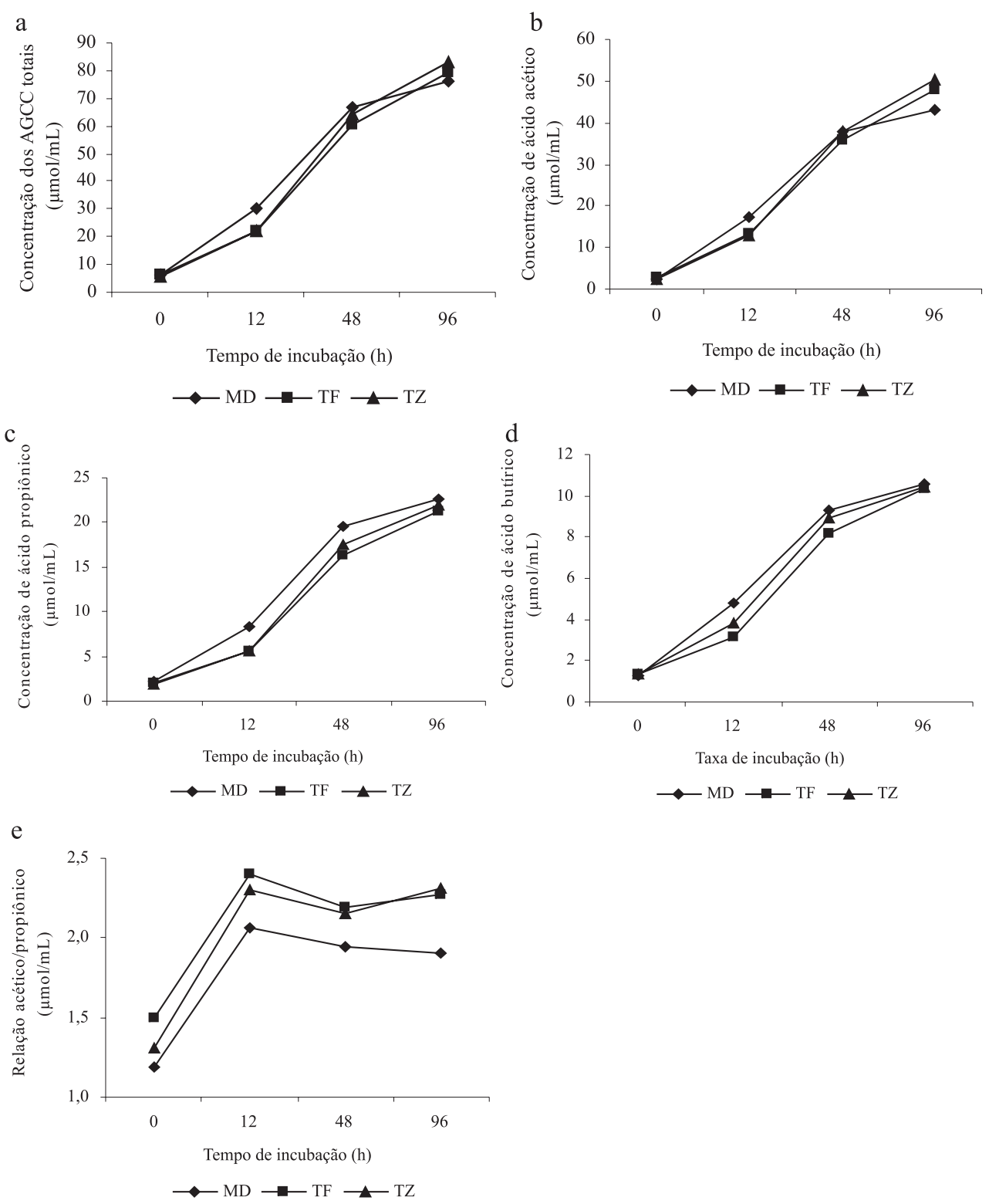

Figura 4 - Concentração de ácidos graxos de cadeia curta totais (a), acético (b), propiônico (c), butírico (d) e relação ácido acético:ácido propiônico (e) após 0, 12, 48 e 96 horas de incubação, no período de janeiro-março. 
a

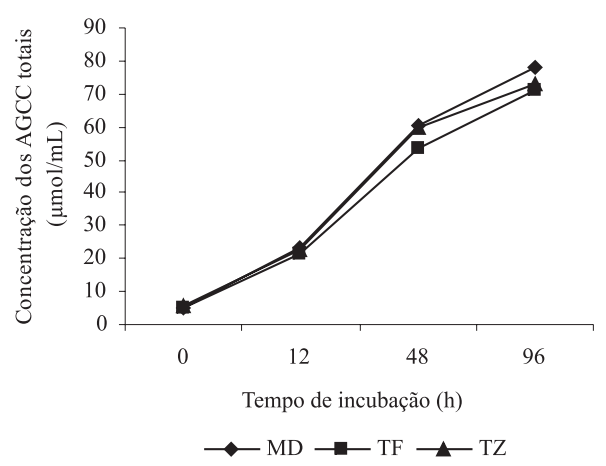

$\mathrm{c}$
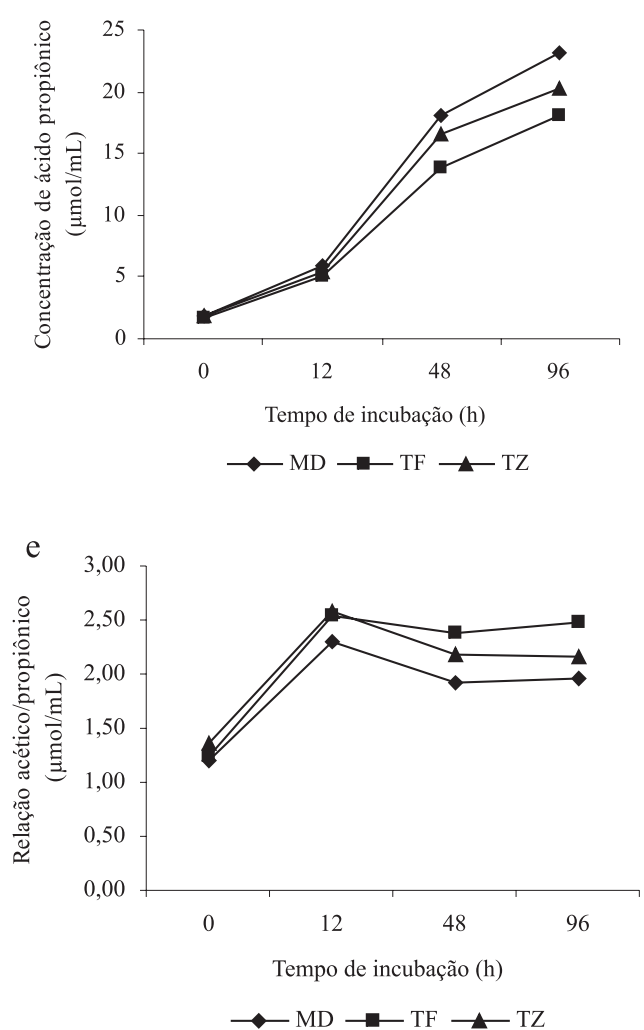

b

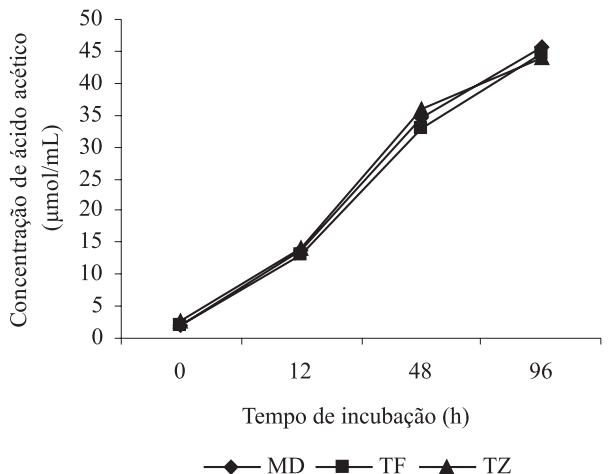

d

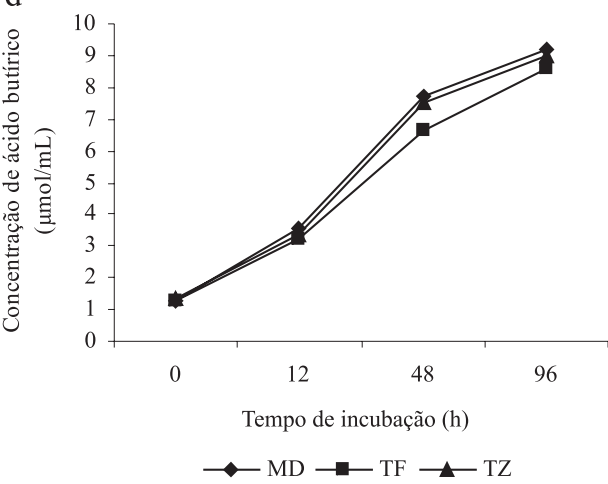

Figura 5 - Concentração de ácidos graxos de cadeia curta totais (a), acético (b), propiônico (c), butírico (d) e relação ácido acético:ácido propiônico (e) após $0,12,48$ e 96 horas de incubação, no período de abril-junho.

foi o capim-tifton 85. A fermentação de gramíneas com idade de corte aos 35 dias destacou-se pela maior produção de ácidos propiônico e butírico.

O avanço no tempo de incubação aumentou $(\mathrm{P}<0,05)$ a produção de ácidos graxos de cadeia curta. A interação espécie $\times$ tempo de incubação promoveu diferenças nas produções dos ácidos graxos propiônico e butírico (Figura 5). Houve interação idade de rebrota $\times$ tempo de incubação para as produções de ácido propiônico e ácido butírico.

Os valores de produção de AGCC obtidos pela técnica de produção de gases nas três gramíneas avaliadas foram inferiores aos encontrados por Manella et al. (2003) no líquido ruminal de bovinos alimentados exclusivamente com capim-marandu, de 65,$7 ; 55,12 ; 7,49 \mathrm{e} 3,1 \mu \mathrm{mol} / \mathrm{mL}$ para AGCC totais, acético, propiônico e butírico, respectivamente.

\section{Conclusões}

O capim-marandu promove os melhores parâmetros de cinética de fermentação e taxas de degradação no período de janeiro a março, independentemente da idade de corte, e apresenta valores semelhantes aos do capimtanzânia no período de abril a junho. No manejo utilizado 
no experimento, o capim-tifton 85 , de crescimento estolonífero, apresenta menor renovação de tecidos na parte aérea e acúmulo de material morto, o que compromete a qualidade do capim e os parâmetros avaliados.

\section{Literatura Citada}

BUENO, I.C.S.; CABRAL FILHO, S.L.S.; GOBBOA, S.P. et al. Influence of inoculum source in a gas production method. Animal Feed Science and Technology, v.123-124, p.95-105, 2005 .

CABRAL, L.S.; VALADARES FILHO, S.C.; DETMANN, E. et al. Cinética ruminal das frações de carboidratos, produção de gás, digestibilidade in vitro da matéria seca e NDT estimado da silagem de milho com diferentes proporções de grãos. Revista Brasileira de Zootecnia, v.31, n.6, p.2332-2339, 2002.

FRANCE, J.; DHANOA, M.S.; THEODOROU, M.K. et al. A model to interpret gas accumulation profiles associated with in vitro degradation of ruminant feeds. Journal of Theoretical Biology, v.163, n.2, p.99-111, 1993.

KOZLOSKI, G.V. Bioquímica dos ruminantes. Santa Maria: Ed. UFSM, 2002. 140p.

LEVENTINI, M.W.; HUNT,C.W.; ROFFLER, R.E. et al. Effect of dietary level of barley-based supplements and ruminal buffer on digestion and growth by beef cattle. Journal of Animal Science, v.68, n.12, p.4334-4344, 1990.

MANELLA, M.Q.; LOURENÇO, A.J.; LEME, P.R. Recria de bovinos Nelore em pastos de Brachiaria brizantha com suplementação protéica ou com acesso a banco de proteína de Leucaena lecocephala. Características de fermentação ruminal. Revista Brasileira de Zootecnia, v.32, n.4, p.1002-1012, 2003.

MAURICIO, R.M.; MOULD, F.L.; DHANOA, M.S. et al. A semiautomated in vitro gas production technique for ruminant feedstuff evaluation. Animal Feed Science and Technology, v.79, n.4, p.321-330, 1999

McDOUGAL, E.I. Studies on ruminal saliva. 1. The composition and output of sheep's saliva. Biochemical Journal, v.43, n.1, p.99-109, 1949.

MEHREZ, A.Z.; ØRSKOV, E.R. A study of the artificial fiber bag technique for determining the digestibility of feeds in the rumen. Journal of Agricultural Science, v.88, p.645-650, 1977

NOGUEIRA FILHO, J.C.M.; FONDEVILA, M.; URDANETA, A.B. et al. In vitro microbial fermentation of tropical grasses at an advanced maturity stage. Animal Feed Science and Technology, v.83, n.2, p.145-157, 2000.

ØRSKOV, E.R.; McDONALD, I. The estimation of protein degradability in the rumen from incubations measurements weighted according to the rate of passage. Journal of Agricultural Science, v.92, n.2, p.499-503, 1979.

SILVA, D.J.; QUEIROZ, A.C. Análise de alimentos: métodos químicos e biológicos. Viçosa, MG: Editora UFV, 2002. 235p.

STATISTICAL ANALYSIS SYSTEMS - SAS. User's guide. Version 8. 1.ed. Cary: SAS Institute, 2001.956p.

STERN, M.D.; BACH A.A.; CASAMIGLIA S. Alternative techniques for measuring nutrient digestion in ruminants. Journal of Animal Science, v.75, p.2256-2276, 1997.

THEODOROU, M.K.; WILLIAMS, B.A.; DHANOA, M.S. et al. A simple gas production method using a pressure transducer to determine the fermentation kinetic of ruminant feeds. Animal Feed Science and Technology, v.48, n.2, p.185-197, 1994. 